\title{
ANAL YSIS OF FACEBOOK COMMENTS ON BBC DOCUMENTARY ON SEX FOR GRADES IN TWO FAMOUS UNIVERSITIES
}

\author{
Daniel Toochukwu Ezegwu, PhD \\ Department of Mass Communication, \\ Samuel Adegboyega University, Ogwa, Edo State \\ Email:ezegwudaniel@gmail.com \\ Phone number: 080-34630757 \\ Mercy Ifeyinwa Obichili, $\mathrm{PhD}$ \\ Department of Mass Communication, \\ Coal City University, Emene, \\ Enugu State, Nigeria \\ Email:mercyifeyinwaobichili@gmail.com \\ Phone number: 070-30988287 \\ Danielle Oare Addeh \\ Department ofMass Communication, \\ Samuel Adegboyega University, \\ Ogwa, Edo State. \\ Phone number: 081-41616292
}

\begin{abstract}
This study analysed Facebook comments on BBC documentary on sex for grade in two famous universities. The objectives of this study were: to find out the frequency of the comments on $B B C$ documentary on sex for grade in two famous universities on BBC news Africa Facebook page, to identify the tone of the comments on sex for grade in two famous universities and to ascertain the dominant mood of the comments on BBC documentary on sex for grade in two famous universities. This study adopted quantitative and qualitative research methods. This study found that the commentators used the Facebook medium to express their views on the BBC documentary on sex for grade in two famous universities, especially after the documentary was posted on BBC Africa Facebook page.It was further discovered that comments posted on the release day of the BBC documentary had 37 (54.40\%) items, while comments posted after DrIgbenegbu's suspension had 31 (45.50\%) items. The dominant tone of the comments was positive. Most of the commentators supported the idea of exposing such crime to the society. The study recommends that media organisation should sustain the online platform as it enables commentators to react to online news and provide an avenue for them to interact with one another and express their opinions on the contents of the article or news events.
\end{abstract}

Key Words: Facebook, Comments, BBC, Documentary, Sex, Universities

\section{INTRODUCTION}

Sexual harassment in tertiary institutions has become a raising global endemic in the last decade. It happens in different spots such as home, school and workplace. According to Akinade (2005), sexual harassment is an unacceptable concept that involves aggression against another person's body or psyche using sex as a weapon. The University of Ibadan, defines sexual harassment as undesired sexually motivated conduct, comments, touching and articulation capable of undermining a person's freedom, rights and privileges. Such acts could include but are not limited to outright demands, ogling, lewd comments and unnecessary bodily contact which could 
lead to psychological or physical unsolicited sexual relationships or unwanted indicative looks, phone calls or use of other multimedia format and comments intended to lure a person into a sexual relationship (The University of Ibadan Sexual Harassment Policy, 2012).

Sexual harassment in institutions of higher learning in West Africa has been an issue that surfaces in the public sphere every now. However, it is usually underreported and swept under the carpet as quickly as it comes. But one question that has attracted global attention was the recent British Broadcasting Corporation (BBC), Africa Eye explosive documentary on Sex for grade reports on the University of Lagos, Nigeria and University of Legon, Accra, Ghana.

In a year-long finding released by BBC on October 6; 2019, a BBC Africa Eye investigation, focused on two of West Africa's leading universities; the University of Lagos and the University of Ghana, which exposed how the epidemic of sex for grades have left several victims traumatised for years. Using undercover reporters posing as students, the documentary revealed how female students are extorted and sexually harassed by male lecturers in exchange for good grades and mentorship. The documentary also concentrates on how lustful academics target the most vulnerable female students; those who were struggling with studies, seeking admission or in search of tutors. Through the use of secret cameras, the undercover reporters captured the gut-wrenching and cringe-inducing dialogues of four predatory lecturers from both institutions as they attempted to cajole and manipulate the undercover journalists into engaging in sexual acts with them.

According to Ibekwe (2019), the most startling case of the four cases of sexual harassment displayed in the documentary was the case of Boniface Igbenegbu, a senior lecturer in the Faculty of Arts of the University of Lagos. They tried to manipulate an undercover reporter posing as a 17-year-old girl seeking admission into the University; Dr Igbenegbu, who betides to be a pastor of Foursquare Gospel Church, a Church with more than 8 million members worldwide, was fingered as a known sexual predator on campus, and He left no one in suspicion about his notoriety as he started making discussions of sexual manner during his first meeting with the undercover reporter (Kiki Mordi). During their second meeting, he was asking the reporter details of her sexual record while promising not to tell her mother.

Oblivious that he was being filmed, he also disclosed how lecturers take female students to a sanctum of some kind of inside the University's Senior Staff Club, by name the 'Cold Room'. Dr Igbenegbu depicted the 'Cold Room' as a gloomy lit room where lecturers engross in forms of casual sexual acts with students. Dr Igbenegbu even attempted to enact what happens in the cold room in his office with the undercover reporter, by switching off the light and inviting her to kiss him. The full hour-long documentary also featured interactions with two lecturers at the University of Ghana. Both of the men, Professor Ransford Gyampo and Dr Paul Kwame Butakor, have denied they were offering "sex for grades" in the undercover exchanges (bbcnewsafrica.com)

Dr Igbenegbu has been suspended by the University of Lagos, while his Church also condemned his act. The film sparked widespread social media comments. The emergence of the internet has encouraged and widened the reach of media organisations and eased audience access to media substances. Through news blogs, Facebook, Twitter, YouTube and Skype platforms, mainstream media organisations are now able to reach a broader audience with news and other contents at little or no costs (Ezegwu, Chime-Ngnya and Obilichi, 2020). One 
of the good qualities of the online news website is that it allows readers to instantly comment on any news story and the comments' section of online media have changed into spaces for debate and discussions by the readers

The World Editors Forum (2013) further posits that for news organisations, online comments can be an extremely precious resource as they supply further detail and insight to articles from sensible readers who are ardent about the subject, offer a broad assort of supplementary opinions and give newsrooms a window into how their readers see both their journalism and the World around them. Their feedback and outlooks can also broaden the publication's coverage from their better point, inspire new stories and provide possible sources or ways to address an issue. Therefore, this study analyse Facebook comments on BBC documentary on sex for grade in two famous Universities.

\section{STATEMENT OF THE PROBLEM}

The airing of BBC Africa Eye documentary sex for grade on October 6; 2019, shook may people and it brought to light the burning issue of sexual harassment in higher institutions across West African. The documentary titled Sex for grade focused on two conspicuous Universities, the University of Lagos (Nigeria) and the University of Ghana where some covert journalists posing as students stealthy filmed their discussions with some lecturers that have harassment allegations trailing them. Dr Boniface Igbenegbu, a former sub-dean of the Faculty of Arts, University of Lagos was one of those caught in the scandal. He was also a pastor of a local Church, Foursquare Gospel Church. He was caught on tape making sexual advances at a covert journalist disguising as a 17-year-old secondary school graduate seeking admission into the Department of European Languages and Integrated Studies where Igbenegbu lectures. The release of the tape on BBC Facebook account has met with tons of comments and mixed reactions on the social media.The agenda-setting role of the media can develop the audience knowledge level and attitude regarding a particular issue. It could also increase or decrease the level of prominence given to items on sexual harassment.

Studies been conducted on sexual harassment around the World, such as: Prevalence of Sexual Harassment of Female Students of TertiaryEducation in Taraba State, North-East Nigeria: Implications for Counselling (Onoyase, 2019), A Survey of Teachers' and Students' Perception of Sexual Harassment in Tertiary Institutions of Edo State, Nigeria (Imonikhe, Idogho and Aluede, 2011), BBC Sex-for-Grades-Report: Nigeria Tertiary Institutions 'Crisis Management Strategies and Stakeholders' Reactions ( Ayinla and Adesola, 2020).Among all these works, none have significantly captured audience reaction on sexual harassment-related issues, most notably on sex for grade between lecturers and students. Thus, this study fills a gap in knowledge by analysing the issue.There is the need to examine different reactions of opinions of online readers, taking into consideration the frequency which such comments come. This heightens some questions, such as: What is the tone of comments and dominant tone of comments on BBC documentary on sex for a grade in two famous Universities on BBC news Africa Facebook page?

\section{OBJECTIVES OF THE STUDY}

The Specific objectives of the research are as follows:

1. To find out the frequency of the comments on BBC documentary on sex for grade in two famous Universities on BBC news Africa Facebook page.

2. To identify the tone of the comments on BBC documentary on sex for grade in two famous Universitieson BBC news Africa Facebook page. 
3. To ascertain the dominant tone of the comments on BBC documentary on sex for grade intwo famous Universities on BBC News Africa Facebook page.

\section{RESEARCH QUESTIONS}

1. What isthe frequency of comments on BBC documentary on sex for grade in two Universities on BBC news Africa Facebook page?

2. What is the tone of comments on BBC documentary on sex for grade in two famous Universities on BBC news Africa Facebook page?

3. What is the dominant tone of the comments on BBC documentary on sex for grade in two famous Universities on BBC News Africa Facebook page?

\section{THE RATIONALE BEHIND THE STUDY AND SIGNIFICANCE OF THE STUDY}

The reasons behind the study were to know how members of the public reacted to BBC documentary on Sex for grade report on two famous Universities in West Africa. Knowing the audience reactions would help to understand what they think and feel about the documentary. Also, the study is also significant as it will serve as reference material for future researchers and contribute to literature in communication field and other related discipline.

\section{SCOPE OF STUDY}

The scope of this study is on analysis of Facebook comments on BBC documentary on sex for grade in two famous Universities. It is restricted to BBC Facebook page specifically BBC news Africa's page on Facebook, October 2019.

\section{LITERATURE REVIEW}

\section{Concept of Social media (Facebook)}

Social media has emerged to be one of the most vital communication means. It exists so as to ease communication among people regardless of the expanse, making it open to people to easily share information, files and pictures and videos, create blogs and send messages, and conduct real-time conversations. These systems are referred to as social, simply because they allow communication with friends, course mates, teachers, project supervisors, lecturers etc so easily and effectively. Social media is a group of internet-based operations that build on the ideological and technological foundations of Web 2.0, and that permit the creation and exchange of user generated content (Kaplan and Haenlein 2010).

In the 2010s, social media applications and websites allow for television displays to be accessed online on a range of desktop and mobile computing devices, smartphones and smart TVs. Many social media websites enable users to post online comments on the programs, both negative and positive in a variety of ways. Observers can actively partake while watching a TV programme by posting comments online, and have their interactions examined and responded to in real-time by other viewers. Technologies such as smartphones, tablets, and laptop computers allow viewers to watch downloaded digital files of TV shows or stream digital files of TV shows on a range of devices, both in the home and while on the go (Wikipedia, 2019).

Mark Zuckerberg in 2005 invented Facebook as a social networking site that acts as a social medium and it has been regarded as the world most popular social media network (Bellis, 2019). The press now provide access for their contents on the internet and makes use of the 
social media platform like Facebook. This is the reason why television stations like African Independence Television (AIT), Silverbird, Channels Television as well as international television station such as British Broadcasting Corporation (BBC), Cable News Network $(\mathrm{CNN})$, to mention a few have found a way to publish the digital format of their contents on the internet and provided a forum for audience feedback and interaction. The media through the use of evolution of Facebook as the top social networking site, television stations via their programmes have taken benefit of a great number of users by creating pages for users to "like", by clicking on the "like" button, showing that they have a positive view of content regarding the show. After clicking "like" on a page, it will then show up under the user's interests.

According to statistics from the Global Digital Report (2014), there is motivation to the growing use of social media by media organisations universally. For example, Reuters Breaking news through the social media network recorded for 1.19 billion users. Over 727 million people use Facebook day-to-day; 260 billion view the Facebook page monthly. Out of this, 100 million users access their Facebook page over mobile phones. It is peculiar that out of these figures from the Reuters Breaking news, 4.3 million are Nigerians, an increase from 400,000 in 1999.This resulted in a meaningful proportion of mobile web traffic in the country (Akinreti, 2013).

With the steady need to partake in up-to-date information, journalists now have to learn how to market their stories and work to get readers to click on and share their stories. Like television news users, online news consumers have special reasons for following particular news organisations and sharing their content.

\section{REVIEW OF RELATED EMPIRICAL STUDIES}

Otikor and Otikor (2018) analysed the patterns of comments adopted by online readers on the electronic version of the Vanguard and the Punch between April 1 and June 30, 2017. The objectives of the study were: To ascertain the number of readers who commented on the comment-thread of news reports of the electronic version of the Vanguard and ThePunch. Find out the frequency of each tone of the comments in the news reports of the newspapers. A total of 182 issues of the electronic version of the two newspapers formed the population of the study, with a sample size of 126.

The content analysis research design was adopted by researchers. Findings showed that 3,189 readers posted comments on the news reports of the two newspapers and that more persons commented on the Vanguard than ThePunch. The study further found out that $52.56 \%$ comments were positive, $43.17 \%$ were negative, while $4.33 \%$ constituted zero comments. The researchers recommended that the electronic newspapers should sustain the online platform to provide opportunities for more participants to engage themselves in discussions which is a critical role that the mass media play in any democratic setting, and that The Punch should improve on its comment platform to attract more participants.

Degarr, BO and Tine (2020) examined online readers' comments on corruption stories and hate speech in Nigeria.The study adopted the critical discourse analysis and purposively examined comments on four high profile corruption stories of 2016 in two national newspapers, Vanguard and Punch. The results showed that the dimension of these conversations sometimes slides into hateful expression that is generally aimed at not just those commenting but the central figure of the corruption story as reported in the news. Such 
hateful expressions are targeted directly at the entire tribe and region of the main actors in the news. The researchers suggested a thorough moderation of readers' comments to guard against comments that tend to portray hate.

Onoyase (2018) investigated the prevalence of sexual harassment of female students of tertiary education in Taraba State North East, Nigeria. The study used a survey research method. The result indicated that there is a frequency of sexual harassment of female students of tertiary education in Taraba State. Sexual harassment of female students' occurred through improper sexual comments, unwanted touching of female students' breasts, tapping of female students' buttocks and tempting of female students with high scores for sex amongst other. The result also revealed that there is no significant difference among the respondents in the universities, polytechnics and colleges of education on the prevalence of sexual harassment of female students. The study recommended that the management of tertiary educational institutions should put in place sufficient measures to ensure that lecturers do not leak examination questions to students.

Imonikhe, Idogho, and Aluede (2011) examined how teachers and students of tertiary institutions in Edo State, Nigeria, perceived sexual harassment. The study adopted survey research method. The sample of the study consisted of two hundred lecturers and 200 students of tertiary institutions in Edo State. The results indicated that majority of the respondents agreed that sexual harassment is prevalent in schools and that sexual harassment impacts negatively on the academic performance of victims. The researchers recommended, among others that tertiary institutions should provide the framework where teachers and students can dialogue on issues bothering on students' and lecturers' relationships.

Ayinla and Adesola (2019) examined the crisis management strategies of Nigerian tertiary institutions and stakeholders' reactions after the British Broadcasting Corporation's sex-forgrades report. They adopted qualitative research design. The study analysed 13 available press releases of institutions retrieved from some institutions' websites and sampled opinions of 20 stakeholders comprising parents, students and lecturers through a in depth interview. The study discovered that the institutions mostly used denial with diminish response strategy to blame societal decadence, scapegoat female students for and downplayed the severity of sexual harassment incidence by the institutions. More so, all the stakeholders distrust the credibility of local media in the reportage of sexual harassment cases. The researchers recommended that Nigerian higher educational institutions should not adopt a denial response strategy for sex scandal cases.

Adedokun, (2005), carried out a study to establish the existence of sexual harassment in University of Lagos, determine its form and degree, document efforts at addressing the problem and explore the link between sexual harassment and the risk of exposure to sexually transmitted diseases including HIV/AIDS. The study involved getting qualitative data from focus group discussions and interviews involving 30,000 male and female students (who had spent at least one academic session in the University) and both academic and non-academic staff of the University. Findings from the study provided evidence of the prevalence of sexual harassment in the University,as every discussant and interviewee, either had an experience or knew other people who have had experience. There was also the consensus opinion that the problem had been on the increase in the last ten years and that male academic staff are the main perpetrators followed by male non-academic staff that oversees admissions, records and exams. Indecent dressing, inevitable failures in the Nigerian educational system, lack $\varnothing$ 
respect for the femalegender and poor performance of some female students were found to be promoting factors of sexual harassment.

Fayankinnu (2004) carried out a study at AdekunleAjasin University, Akungba - Akoko Ondo State in which 200 students were interviewed using a questionnaire. The findings revealed that males, female lecturers and students are harassers. The study also revealed that male lecturers $(83.4 \%)$ and female students $(65.6 \%)$ were the major harassers. On how female students harass the male lecturers, the study revealed that they do so through their mode of dressing $(70.2 \%)$, visits to their offices at odd times $(52.9 \%)$, buying gifts such as pants or pornographic tapes (64.2\%), passing pleasant remarks about lecturers $(55.0 \%)$ and telling lecturers indirectly that they want them (59.7\%). The study reported that inspite of the prevalence of the phenomenon; minimal efforts are taken to address the problem.

The literature reviewed revealed that sexual harassment in the Universities is prevalent and happens in most institutions. Also, online commentators sometimes slide into hateful expression and use fowl languages in expression of their views. Also, literatures are lacking on Facebook comments on BBC documentary on sex for grades in two famous universities. This is the major lacuna which the present study attempts to fill.

\section{THEORETICAL FRAMEWORK}

\section{Technology Determinism theory}

This study is anchored on technological determinism theory. The Media Technological Determinism theory was propounded by Marshall McLuhan in 1964 and founded on technological innovations. The basic assumptions of the theory, according to McQuail (2010) are that: "communication technology is fundamental to society; that each technology has a bias to particular communication forms, content and uses, the sequence of invention and application of communication technology influences the direction and pace of social change, and that communication revolutions lead to social revolutions" (p.103).

The bane of this theory is that technology in any given society defines its nature. Technology is regarded as the exerting force of culture in a community, and it determines its course of history. Karl Marx affirmed that technological progress leads to newer ways of production in a society and this eventually influenced the cultural, political and economic aspects of a community, thereby unavoidably changing culture itself. New media are not only an addition to existing media, but are also new technologies and thus do have a deterministic factor as the introduction of newsprint, television and the internet have all shown how technological advances have an impact on the society in which we live in. Technology inevitably causes specific changes in how people think, in how society is structured, and in the forms of culture that are created (Baran and Davis, 2012).

McLuhan as cited by Ekwenchi, Chiaha, andAbuah, (2015) asserts that alterations in communication technology necessarily produce profound changes in both culture and social order. The theory helps to explain in this study that technology determines how the audience members respond to news items because technology gave the means. The approach sees technology as the basis of all human activity and since media is an aspect of human business; it has been dramatically influenced by the social media platforms such as Facebook, YouTube, and Twitter, Google plus, Skype, Blog and others which are by-product of the 21st century media technology (Akinreti, 2013). 
Technology determinism theory focuses on how the media using the internet or social media places emphasis on specific events or happenings in the society that become the point of discussion among the targeted audience. Concerning the study, it shows that social media users used social networking sites like Facebook to air their opinions on BBC sex for grade documentary in two famous Universities.

\section{RESEARCH METHODOLOGY}

This study adopted quantitative and qualitative content analysis method which is the analysis of existing manifest contents of communications. Nwodu (2017) observes communication scholars often use this research method to investigate the level of presence of a given content in mass communication primarily to establish the impact of such comment on the audience. The content refers to words, meanings, pictures, symbols, ideas, themes, or any message that can be communicated. The text is anything written, visual, or spoken that serves as a medium for communication.

The quantitative content analysis method was used for data presentation (nominal level data measurement). Quantitative data analysis is helpful in evaluation because it provides quantifiable and easy to understand results (Pell Institute, 2016). While qualitative content analysis used critical discourse to analyse the pattern of Facebook comments on BBC documentary on sex for grade in two famous Universities. According to Hililary (1997), critical discourse analysis stems from a critical theory of language which sees the use of language as a form of social practice. Critical discourse according to Johnstone (2008) is a form of discourse analysis that studies the relationship between discourse and ideology (a set of belief) attitudes and perspectives in the world. It dwells on critiquing social injustice, and has strong links to the study of language and power. This approach is adopted to study the texts along the line of the ideologies expressed with emphasis on the objectives of the study. According to Daymon and Holloway as citied by Wimmer and Dominik (2011), researchers who use discourse analysis look at three specific aspects of language: The form and content of the communication used, the ways people use word to communicate ideas and beliefs and institutional and organisational factors that might shape the way the word is used.

The core informed the choice of critical discourse analysis, which is to analyse audience comments on the BBC documentary on sex for grade in two famous Universities. It will also help to understand how they express their position or view concerning sex for grade issues in the Universities. The study population comprised the total number of comments posted by Facebook users on the sex for grade documentary via the BBC News Africa Facebook page. This broadcasting page of BBC News Africa was purposively chosen because of their promptness in sharing or posting news stories about the documentary via their Facebook page.

As a result of other constraints and researchers discretion, it is impractical to study the whole comments from all the posts concerning the story posted by BBC Africa's Facebook page. However, the systematic random sampling was employed in selecting the remarks at a fixed interval of after selecting two posts which had the highest comments and shares which was posted 6th, October and 8th, October 2019. In all 1350, comprising of the comments on the release date of the documentary had 737 comments and the post-suspension of Dr Boniface Igbenegbu who was one of the lecturers caught in the sex for grade documentary had 613 comments which gave us a total of 1350 observations. For the sample, 5\% was drawn from 
the population, resulting in a sample of 68 observations from the selected post. To ensure that each post is fairly represented, $5 \%$ of the total comments for each post were selected.

The unit of analysis in this study consist of individual comments posted on BBC News Africa Facebook page in relation to the documentary on sex for a grade in two famous Universities. In using this research approach, the need to define and categories the contents to be analysed into which unit of analysis are huddled, is also necessary. These are the content categories for the study; they are:

- Positive comments: These are comments that praised Kiki Mordi and the BBC for carrying out such investigation and advocated against the act of sexual harassment of students by lecturers in universities.

- Negative comments: These are comments that blamed the students for the act and not the lecturers who were seen as perpetrators in the documentary.

- Media imperialism: These are comments that criticised the documentary and the fact that it focused on universities in Africa.

- Neutral comments: This category of comments had no issue with the fact that it was conducted in Africa or how the investigations were carried out. Instead, they were thoughtful and objective comments that were made without any form of sentiments.

\section{DATA PRESENTATION AND ANALYSIS}

Table 1: Distribution of comments on BBC documentary on sex for a grade in two famous select Universities

\begin{tabular}{|l|l|l|}
\hline Variable & Frequency of comments & Percentage (\%) \\
\hline $\begin{array}{l}\text { Comments posted on the release } \\
\text { of the documentary }\end{array}$ & 37 & 54.40 \\
\hline $\begin{array}{l}\text { Comments posted after the suspension } \\
\text { of DrBonifaceIgbenegbu }\end{array}$ & 31 & $45.50 \%$ \\
\hline Total & 68 & 100 \\
\hline
\end{tabular}

Source: Field survey, 2020

The table above indicates that comments posted on the release day of the BBC documentary have the highest percentage $(54.40 \%)$ of comments, it then followed by remarks posted after Dr Igbenegbu's suspension.

Table 2: Distribution of tone of comments on BBC documentary on sex for grade in two famous Universities

\begin{tabular}{|l|l|l|l|c|}
\hline $\begin{array}{l}\text { Tone of the } \\
\text { comments }\end{array}$ & $\begin{array}{l}\text { Comments posted on the } \\
\text { release day of the } \\
\text { documentary }\end{array}$ & $\begin{array}{l}\text { Comments posted } \\
\text { after } \\
\text { the suspension of } \\
\text { DrIgbenegbu }\end{array}$ & $\%$ \\
\hline Positive & 13 & 15 & 28 & 41.17 \\
\hline Negative & 5 & 4 & 9 & 13.2 \\
\hline $\begin{array}{l}\text { Media } \\
\text { imperialism }\end{array}$ & 8 & 3 & 11 & 16.17 \\
\hline Neutral & 10 & 9 & 68 & 27.8 \\
\hline Total & 37 & 31 & & \\
\hline Source: Field survey, 2020 & & & \\
&
\end{tabular}


Volume 1 Number 1 Maiden Issue

The analysis of table 2 above indicated the tone of comments employed by Facebook users to express their views on BBC documentary on sex for a grade in two famous Universities.

Table 3: Dominant tone of comments on BBC documentary on sex for a grade in two famous Universities

\begin{tabular}{|l|l|l|l|l|}
\hline The tone of comments & $\begin{array}{l}\text { Comments posted on } \\
\text { the release day of the } \\
\text { documentary }\end{array}$ & $\begin{array}{l}\text { Comments posted } \\
\text { after } \\
\text { the suspension of } \\
\text { DrIgbenegbu }\end{array}$ & Total & $\%$ \\
\hline Positive & 13 & 15 & 28 & 41.17 \\
\hline Negative & 5 & 4 & 9 & 13.2 \\
\hline Media imperialism & 8 & 3 & 11 & 16.17 \\
\hline Neutral & 10 & 9 & 19 & 27.8 \\
\hline Total & 37 & 31 & 68 & 100 \\
\hline
\end{tabular}

Source: Field survey, 2020

Table 3 above showed the dominant tone of comments, which are positive comments. Facebook users made positive comments to express their views on BBC documentary on sex for grade in two famous Universities. The implication of the data presented above is that majority of the Facebook users expressed their views positively on BBC documentary on sex for grade in two famous Universities.

\section{DISCUSSION OF FINDINGS}

\section{Research Question One: What is the frequency of comments on BBC documentary on "sex for grades" in two famous Universities on BBC news Africa Facebook page?}

The findings revealed that comments posted on the release day of the BBC documentary had $37(54.40 \%)$ items, while comments posted after Dr Igbenegbu's suspension had $31(45.50 \%)$ items. These indicated that commentators used the Facebook medium to express their views on the BBC documentary on "sex for grades" in two famous Universities, especially after the documentary was posted on BBC Africa Facebook page. The online platforms have enabled readers/commentators to interact with peopleof diverse ethnicity/tribes.

No wonder Natalie and Holmes (2013) observe that comments in reaction to online news provide an avenue for readers to interact with one another, express their opinions on the content of the article or remark of others. Commenters may also change what they perceived to be half-truths in the comments of other readers, provide support, facts and links to the websites with more relevant content. This interaction among readers creates a conversation in which ideas are debated and negotiated (Natalie and Holmes 2013, as cited in Oyedele and Agberu, 2018). Also, the ability of people from different parts of the world to air their opinions via BBC Facebook page on sex for grade in two famous Universities showed the power of social media, linking people together, irrespective of their locations/distance. This agrees with the "global village" assertion of Marshal McLuhan (1964) as expressed in his technological determinism theory. Time and distance barriers no longer limit communication. With social media, we are already in the 'global village'. Thus, powered by technology, the social media facilitates the interactivity and diversity of views or opinions. 


\section{Research Question Two: What is the tone of comments on BBC documentary on "sex for grade" in select West African Universities on BBC news Africa Facebook page?}

The findings showed that the commentators employed varieties of tone in their comments as identified in the study, which includes: Positive, negative, media imperialism and neutral comments. We align our finding with assertion by Chung (2008), Manosevitch and Walker (2009) that readers' comments posted in response to on-line news articles are a form of participatory journalism that gives the public a medium for expressing their perspectives on current issues. Comments have the potential to increase our understanding of public opinions, how the public makes decisions and how beliefs are formulated. Also, Henrich and Holmes (2013) observe that comments have the potential of increasing our understanding of public opinions, how the public makes decisions and how beliefs are formulated.

.Research Question Three: What is the dominant tone of the comments on BBC documentary on "sex for grade" in select West African Universities on BBC News Africa Facebook page?

The aim of this research question three is to identify the dominant comments as posted by the audience to the BBC Africa home page. The data in table 3 showed that out of 68 items analysed, the dominant tone of comments onthe BBC documentary on sex for grade in two famous Universities was positive comments with $28(41.17 \%)$ items. Others include: Neutral comments (27.8\%), media imperialism comments (16.17\%) and negative comments $(13.2 \%)$. These findings revealed that most people liked the BBC investigation as well as the suspension of Dr Boniface Igbenegbu. They supported the idea of exposing such crimes to society.These findings correlate with scholars who argue that most people online are far more likely to be nice than resort to rude, hostile, and uncivil communicative behaviour.The result is also consistent with that of Ollay and Ekhareafo (2013), who did a textual analysis of theJanuary, 2012 anti-subsidy removal protests in Nigeria.They found that $70.5 \%$ of texts messages and comments on social media were positive and in support of the protests.

\section{Few examples of positive comments are:}

"Well done BBC news to reveal the evil act by some lecturer in our high institution, Nigeria government BBC has started so finish it" (BBC News Africa, October 2019).

"A project supervisor in one of Nigeria Universities, asked my sister to pay him \#50,000 to supervise her work. Or he will sleep with her. The lecturer even invited her to a hotel in town. My sister informed me about it, and luckily I was in Nigeria then. And the rest was the case. EXPOSE THEM" (BBC News Africa, October 2019).

"Those ladies involved need to speak up, These Abominable acts need to stop. Dismissing the lecturer when caught in the act should be one of the best solution, or probably Prison sentences should be another vital solution" (BBC News Africa, October 2019).

"Suspending d lecturer is not enough those found guilty should be locked in cold room too freeze for $30 \mathrm{~min}$, the University of Lagos cold room is a collaborated and organised by those dirty lecturers they should b fish out.." (BBC News Africa, October 2019)

These comment under this category encouraged universities and the legislature to act and make laws and policies that can remove this menace from the education system.

Few examples of negative comments are:

"In as much as you try to expose these lecturers $n$ bring sanity to our public universities, you need to be circumspect in your dealings, $n$ you shouldn't end up rendering breadwinners 
jobless. Mind $u$, some of these female students are already gold diggers, or if $u$ want to slay queens, $n$ they hardly have time for their handouts" (BBC News Africa, October 2019)

"It's a traditional norm in higher institutions in Nigeria, so I don't think it's should be cast this way; the people who reported this menace are just being extra."

"Next joke, please! This is no news! BBC News, please don't disappoint. There are better issues to report on than things we know already from the beginning of creation, and you want make it look new. Stop accusing the dog of barking” (BBC News Africa, October 2019)

"This happens in everywhere across the globe, stop shaming Africa,by Africans as you are yourselves. Develop your minds. Nowonder you're refereed as monkeys!!!" (BBC News Africa, October 2019).

"Please also focus on Muslims lecturers, not just Christians; or is your spy journalist afraid. All those investigated are Christian please we don't want biased investigation."

\section{Examples of comments which fall under media imperialism include:}

" $B B C$ is doing the right thing by exposing such. My worry, however, is BBC should at least say something good about Africa for once. I'm yet to read a piece of positive news about Africa from the BBC" (BBC News Africa, October 2019).

"Why not Harvard and Oxford, but Ghana and Nigeria are those school saints what a waste of time. Leave Africa matter to us and focus on your numerous scandalous issues in the west, rubbish" (BBC News Africa, October 2019).

"BBC should focus on Sex for Grades in Oxford, Harvard and other top-class Universities in the Developed World. Who doesn't know Lecturers all around the World Eat "Shi" for good grades? This is a list to put Africa up again for ridicule. The whites keep bringing us down" (BBC News Africa, October 2019).

\section{Examples of comments which fall under neutral include:}

"This is why I don't like the education system of having the same person teaching you to mark your exam common in academic courses. Where is the independence? And if they hate you, then you will never pass. I have never liked the idea of having a lecturer teaching me and the same one marking me. Even those who are not supposed to pass get high grades than intelligent ones because of biasness. I am glad I went the professional way of studying where there is no compromise. The systems need to change, and exams should be given and marked by independent examiners. Zambia" (BBC News, Africa, October 2019).

"I suggest the government should have agencies that will work with the students' affairs government where students will have free access to share their views as regards to all this harassment and abuses in our institutions and laws will be enshrined for the culprit, then the identity of such student that fall to victim of their harassment will also be protected with the law to sanction other staff colleagues from threatening such individual in her studies." (BBC News Africa, October 2019)

"Is from VC to the lecturers, is a corrupt system. Some of our ladies are really enjoying it, while some are the recruiters and advisers, some are dying in salient. Lets encourage them to come out and talk. Let there be an establishment body where victims can report with full confidence and get Justice” (BBC News Africa, October 2019).

\section{CONCLUSION}

This study examined Facebook comments on BBC documentary on sex for a grade in select WestAfrican universities. Based on the findings, we submit that the commentators used the Facebook medium to express their views on the BBC documentary on "sex for grade" in select West African Universities, especially after the documentary was released or posted on 
BBC Africa Facebook page. We also conclude that the commentators employed varieties of tone in their comments as identified in the study, which includes: Positive, negative, media imperialism and neutral feedback. The dominant tone of comments was positive. Most of the commentators supported the idea of exposing such crime to the society. The effect of sexual harassment any place in the World no doubt is devastating, traumatically affecting the victims as much as those directly or indirectly linked to them. Thus, efforts must be made to prevent it.

\section{RECOMMENDATIONS}

Based on the findings, the following were recommended:

1. There is need for media organisations to sustain the online platform as it enables commentators to react to online news and provide an avenue for them to interact with one another and express their opinions on the contents of the article or news events.

2. The positive tone of comments should be sustained to ensure the free expression of ideas and reorient the minds of commentators/readers to make the useful suggestion that will foster national development. Use of foul languages, derogatory words, name-calling and prejudicial posts should be moderated on social media platforms.

3. Institutions of higher learning need to update their discipline procedures to address sexual harassment by providing clear information on how to report an incident and offer more significant support for students who report harassment.

4. Higher institutions of learning should organise periodic training and campaign for staff and students on sexual harassment as it will help in keeping the scourge on the front-burner of such institution life.

Research work should be carried out on the media coverage of Sexual harassment-related issues and the effect it has on the audience in Nigeria and other parts of Africa.

\section{REFERENCES}

Akinade, E. A. (2005). Dictionary of Guidance and Counselling. (Counselling Psychology, Ibadan: Olu - AkinPublishers.

Akinreti, Q. O. (2013). The utilisation of social media platforms for a television broadcast: A case study of channels television in Nigeria. Retrieved December 23, 2019 from https://www.academia.edu/24585815/the_utilisation_of_social_media_platforms_for_ tele vision_broadcast_case_study_of_channels_television_in_nigeria

Ayinla, F.I. and Adesola, B.N (2019). BBC Sex-for-Grades-Report: Nigeria Tertiary Institutions 'Crisis Management Strategies and Stakeholders' Reactions. The Journal

of $\quad$ Society and Media, 4(1), 156-179.

Adedokun, O. (2005). Sexual harassment in Nigerian Educational Settings:Preliminary notes from a qualitative assessment of' Lagos StateUniversity. Sexuality in Africa, 2 (4), 1622.

BBC News Africa (2019, October, 7). Sex for a grade. Retrieved from https://www.facebook.com/pg/BBCnewsafrica/posts/?ref=page_internal

BBC News Africa (2019, October, 8). Lecturer suspended after sex for grade film. Retrieved from https://www.facebook.com/pg/BBCnewsafrica/posts/?ref=page_internal 
Baran, S. J and Davis, D. K. (2012). Mass Communication Theory: Foundations, Ferment and Future ( $6^{\text {th }}$ ed.) Wadsworth: Cengage Learning.

Bellis, M. (2019). The History of Facebook and How It Was Invented. Retrieved December 15; 2019, from https://www.thoughtco.com/who-invented-facebook-1991791.

Chung D. (2008). Interactive features of online newspapers: Identifying patterns and predicting use of engaged readers. J. Comput. Mediat. Comm. 13, 658-679.

Degarr, H, Bo, D. I. and Tine, V.A. (2020). Online Readers' Comments on Corruption Stories and Hate Speech in Nigeria.IOSR Journal of Humanities and Social Science, 25 (3), 49- 59.

Ezegwu, D.T, Chime-Ngnya C. R and Obilichi, M. I. (2020).Stay at home and be safe: Online newspaper readers' comments on lockdown of select states in Nigeria by President Muhammadu Buhari. FUOYE Journal of Communication, 4,

Ekwenchi, C.O, Chiaha, C. and Abuah, F. A. (2015). The impact of online feedback on the credibility of news stories: A study of Saharareporters.com. New Media and Mass Communication, 44, 100-111.

Fayankinnu, E. A.(2004). Ethnics and Sexual harassment in staff/students relations: Who harasses who?" Nigerian Social Scientist, 13-18.

Henrich, N. and Holmes, B. (2013).Web news readerse comments: Towards developing a methodology for using on-line comments in social inquiry. Journal of Media and Communication Studies, 5 (1), 1-4.

Hilary, J. (1997). Critical discourse analysis as a research tool discourse. Studies in the Cultural Politics of Education, 18(3), 329-342.

Ibekwe, I. (2019). BBC investigation uncovers Nigerian, Ghanaian academics sexually harassing students for a grade. Retrieved on May 12; 2020, from www.premiumtimesng.com

Imonikhe, J, Idogho, P, Aluede, O. (2011).A survey of teachers' and students' perception of sexual harassment in tertiary Institutions of Edo State, Nigeria.International Multidisciplinary Journal, Ethiopia 5 (5), 412-423.

Johnstone B (2008).Critical Discourse analysis (2nd ed.) Oxford:Blackwell.

Kaplan, A., \&Haenlein, M. (2010). Definition and Classification of Social Media. Business Horizons, 53 (1), 59-68.

Manosevitch E, Walker D (2009). Readers' comments to online opinionjournalism: A space of public deliberation. 10th International Symposium on On-line Journalism. Houstin, Texas.

McQuail, D. (2010). McQuail's Communication Theory. London: Sage Publications. 
Nwodu, L. C. (2017). Research in Communication and other Behavioural Science: Principles, Methods and Issues, ( $2^{\text {nd }}$ edition). Enugu: Iykeventutes.

Ollay O.W, Ekhareafo O.D (2013). Social media as people's power: Atextual analysis of the January 2012 anti-fuel subsidy removal. TheNigerian Journal of Communication $11(1) \quad 25-57$.

Onoyase, A. (2019). Prevalence of sexual harassment of female students of tertiary education in Taraba State, North-East Nigeria: Implications for counselling. International Journal of Higher Education, 8(1), 77-83.

Oyedele, O. J \&Agberu, O.A. (2018). Analysis of online readers' comments on news stories about Chibok girls' release published by the Sahara Reporters and the Vanguard newspapers.Fuoye Journal of Communication, 2018, 2, 130-150.

Otikor and Otikor (2018). Patterns of comments by online readers of the electronic version of Vanguard and the Punch newspapers (April-June, 2017).Research Journal of Mass Communication and Information Technology, 4 (1), 13-25.

Pell Institute (2016). Analyze quantitative data.

Usman, E. (2018). Sex for marks in Nigerian Universities. Retrieved on May 25; 2020, from www.vanguardng.com

University of Ibadan (2012) Sexual Harassment policy, Retrieved December 12; 2019, from https://www.ui.edu.ng/news/sexual-harassment-policy

Wimmer, R. D., and Dominick J. R. (2011). Mass media research: An introduction. Wadsworth Cengage Learning.

Wikipedia (2019). Social media and television. Retrieved December 22; 2019, from https://en.wikipedia.org/wiki/Social_media_and_television

World Editors Forum (undated). Online Comment Moderation: Emerging Best Practices. A companion to promoting robust and civil online conversation. AFPF_ENG_online_excerpts_final. View publication. 